\title{
A responsabilidade civil das unidades federadas pela edição de leis concessivas de benefícios fiscais tributários sem resolução autorizativa do CONFAZ
}

\section{Civil liability of editing by federated units concessive laws of tax benefits tax without the resolution authorizing CONFAZ}

\section{Resumo}

O presente artigo discorre sobre a responsabilidade civil dos Estados brasileiros pela concessão de benefícios fiscais por meio de leis julgadas inconstitucionais, com efeitos desde sua vigência, e a hipótese de exigibilidade, por força do art. $8^{\circ}$, II da LC n ${ }^{\circ} 24 / 75$, dos valores desonerados das empresas. Nessa perspectiva, admitimos a possibiliade de as empresas ajuizarem ações indenizatórias ante os Estados e, preenchidos os requisitos, serem indenizadas, no mínimo, pelos investimentos realizados no território estadual, pois, agiram segundo legislação vigente à época, debaixo da confiança legítima, e crendo na segurança jurídica ínsita na contratação com um Ente público.

Palavras-chave: Responsabilidade civil. Estado. Benefício fiscal. Lei inconstitucional. Reparação de danos. Possibilidade.

\begin{abstract}
This article discusses the civil responsibility of the States for the concession of tax benefits through laws which were judged to be unconstitutional, effective since its validity, and the hypothesis of enforceability, in light of article $8^{\circ}$, II from LC $n^{\circ} 24 / 75$, of the amounts unencumbered from the companies. In this perspective, we admit the possibility of the companies to judge actions for damages before the States, and once the requirements are fulfilled, to be indemnified, in the least, for the investments done in the state territory since they acted according to the current legislation at the time, under legitimate trust and believing in the legal safety inapt in the contract with a public entity.
\end{abstract}

Keywords: Responsibility civil. State. Benefits through. Laws unconstitutional. Actions for demages. Possibility. 


\section{Introdução}

Nosso intento, por meio deste artigo, é tratar questão de tão difícil concordância na doutrina, qual seja, a utilização do instrumento da responsabilização dos Estados pela edição de leis concessivas de benefícios fiscais tributários, quando desprovidas de prévia autorização do CONFAZ.

Diz-se de difícil concordância, porque é sabido que, embora a teoria da responsabilidade civil dos entes públicos seja realidade para o Direito moderno, há, ainda, restrições quanto a sua aplicação quando decorrer da edição de leis, por inúmeras justificativas sedimentadas na história do Direito, a começar pelo princípio da soberania dos Estados, e seguido por tantos outros.

Todavia, acreditamos que os argumentos que davam suporte a esses fundamentos limitadores da responsabilização dos Estados, pela edição de leis geradoras de prejuízo a particulares, têm cedido ante as novas compreensões e dinâmica em que o mundo se organiza e do modo como o direito a essas novas realidades se entremeiam e se manifestam, de modo a não ser mais absurda a ideia de responsabilizar o Estado por causar dano a particular quando editar leis tidas por inconstitucionais.

No caso específico, centramos nossa análise na matéria do Direito Tributário, destacando a situação em que unidades federativas legislam contrariamente ao que está posto pelo ordenamento jurídico pátrio, concedendo benefícios fiscais na expectativa de angariar para seu território investimentos empresariais de modo a gerar em seus limites empregos, desenvolvimento regional, econômico e social, e, por díspare que possa parecer, ampliação das receitas tributárias em um espaço médio de tempo.

Essa tem sido uma realidade brasileira não muito recente, todavia, só há pouco recebendo sinalização jurídica firme da impropriedade das ações nesse sentido, quando o Supremo Tribunal Federal julgou 14 Ações Diretas de Inconstitucionalidade rechaçando a possibilidade de concessão unilateral de benefícios fiscais. Por isso, cremos que o momento é não só auspicioso para tratar dessa temática, como agora, com mais elementos a balizar o entendimento que vamos expor neste trabalho.

A expectativa não é criar embaraços para os entes públicos nem para seus gestores e muito menos obnubilar a dura realidade que os entes federados vivem para con- seguir promover o desenvolvimento merecido para seus rincões, na expectativa de ter oportunidades de boa qualidade de vida para seus cidadãos, por meio de melhoria na infraestrutura, na saúde, na educação e na segurança, entre outros, mas, antes de tudo, demonstrar que, sem o respeito ao ordenamento jurídico - alicerce indispensável à construção de dias melhores -, só se estará deslocando as riquezas de um lado para outro, sem contribuir para a solidez e a disseminação a todos do progresso perseguido.

\section{Quanto ao cabimento de responsabilização do ente público por edição de leis inconstitu- cionais}

\subsection{Histórico e evolução do ordenamento jurídico brasileiro quanto à responsabilidade civil do estado por atos de seus agentes}

No Brasil, percebe-se claramente como se deu a evolução da responsabilização civil do Estado por atos de seus agentes. A Carta Imperial previa em seu art. 179, XXIX e XXX a responsabilidade dos empregados públicos em situações específicas, embora silente quanto à responsabilização do próprio Estado.

Com a Constituição Republicana de 1891, deuse a primeira sinalização da responsabilização do Estado, em seu art. 82, por meio do entendimento de que o Estado seria responsável pelos atos de seus funcionários, sendo necessária a ação regressiva contra o causador da condenação da União.

A Carta de 1934, nos $\$ \$ 1^{\circ}$ e $2^{\circ}$, do art. 171, constou a previsão da responsabilidade solidária da Fazenda Pública quando causasse prejuízos por intermédio de seus funcionários.

A Constituição de 1946 previu no art. 194, parágrafo único, o princípio da responsabilidade objetiva do Estado, sendo essa a mesma linha adotada pela Carta Política de 1967, em seu art. 105, parágrafo único, e na Constituição de 1969, que na Emenda nº 1 manteve a redação existente.

Agora, com a vigente Constituição de 1988, tal princípio encontra respaldo no art. $37, \S 6^{\circ}$, com a seguinte dição:

As pessoas jurídicas de direito público e as de direito privado prestadoras de serviços públicos responderão pelos danos que seus agentes, nessa qualidade, causarem a terceiros, assegurado 
o direito de regresso contra o responsável nos casos de dolo ou culpa.

Pois bem, o avanço se deu com a Constituição dita cidadã pelo fato de não mais apenas as pessoas jurídicas de direito público responderem pelos danos causados por seus agentes, mas, também, as pessoas jurídicas de direito privado que prestarem serviços públicos, ampliando, assim, o leque de responsabilização civil por atos inerentes ao Estado, ainda que prestados por empresas privadas.

É a isso que se diz teoria do risco administrativo, id est, o fato de o Estado ter que responder por atos de seus agentes ou por prestadores de serviços públicos que, nessa qualidade, causarem danos a terceiros, assegurando o direito de regresso, seja por culpa ou por dolo.

Para caracterizá-la, portanto, é imprescindível que o agente esteja em pleno exercício de suas atividades públicas, e a existência de nexo de causalidade entre a conduta do agente e o dano produzido, cabendo a excludente de culpa exclusiva da vítima. A responsabilidade, no caso, é extracontratual ou aquiliana porque oriunda de ato lícito ou ilícito.

\subsection{Responsabilidade civil pela edição normativa estatal. possibilidade}

Já mencionamos alhures, ainda que suscintamente, sobre a evolução da compreensão quanto à responsabilização civil do Estado por atos de seus agentes, ainda que limitadamente ao ordenamento jurídico pátrio.

Assim, mesmo depois de estabelecido o reconhecimento dessa responsabilização estatal, permeia na doutrina que a regra é não haver responsabilidade civil por atos do legislativo, pois o ato normativo trata de emanação da soberania estatal, como uma ferramenta de paz social, sendo que o ônus de se viver em sociedade é ter de suportar as mitigações à liberdade individual.

Todavia, considerando, como vimos em linhas pretéritas, que o dispositivo constitucional ampliou o conceito intencionalmente ao mencionar "agentes" no lugar de "funcionários", não podemos mais enxergar como exceção a responsabilização do Estado pela sua produção legislativa de dispositivo inconstitucional, seja material, formal ou por omissão, quando, efetivamente, venha a ferir direitos dos cidadãos ou que provoque limitações em demasia a alguns sujeitos passivos, pois, se assim não fosse, o Estado se transformaria em um leviatã absoluto, como na obra de Thomas Hobbes. Ademais, há que se entender como ultrapassada a bipartição dos atos estatais em "de império" e "de gestão", em que somente os últimos poderiam gerar responsabilidade civil, sobretudo, em razão do processo de judicialização no Ocidente onde o Poder Judiciário tornou-se, cada vez mais, interventor, mormente quanto aos direitos fundamentais. Isso tem se firmado e, por consequência, sido maioria na doutrina e na jurisprudência, sob fundamento da "[...] quebra dos princípios do pacto vivencial da sociedade"2.

\subsection{Pressupostos específicos para a configuração da responsabilidade civil por atos legislativos}

Uma vez compreendido que não só é possível a responsabilização do Estado pela ação de seus agentes quando gerarem danos a terceiros, mas que isso não implica mais em situação excepcional, vamos examinar aqui quais os requisitos indispensáveis à caracterização dessa circunstância que impõe ao Estado responder civilmente perante terceiros, prejudicados pela edição de atos legislativos.

Para isso, é preciso ter em mente que o Supremo Tribunal Federal entende que norma declarada inconstitucional é norma nula, sendo sua sentença de natureza declaratória, portanto, não importa em revogação, mas em invalidade, e consequente retirada da eficácia.

Logo, nessa linha, temos que o primeiro pressuposto é que seja a decisão declaratória de inconstitucionalidade de lei definitiva por parte do STF. Adiante, como segundo pressuposto, que tenha a lei declarada inconstitucional produzido algum tipo de efeito, não sendo caracterizado se for destituída de eficácia. E, por fim, que haja comprovação do nexo causal entre a norma viciada e o evento danoso, sendo que o dano não pode ser genérico, mas especificado, como um direito já incorporado ao patrimônio.

\subsection{Hipóteses de responsabilidade civil por atos legislativos}

Embora já tenhamos pincelado sobre essa matéria alhures, cremos ser útil destacar aqui, sinteticamente, as hipóteses de responsabilidade civil por atos legislativos do Estado.

\footnotetext{
2 BRASIL. Supremo Tribunal Federal. ADInMC 1.063-8, Rel. Min. Celso de Mello, DJ 27-4-2001.
} 
A princípio, é preciso que haja liame obrigacional resultante de uma inconstitucionalidade por ação, formal ou material, sendo essa a causa mais frequente de dano por produção normativa. Destacamos que o dano tem que ser direto, nunca por via incidental.

Todavia, há também a possibilidade por ausência de produção normativa, impedindo o cidadão de utilizar um direito que lhe fora conferido. Para essa configuração, mister um lapso de tempo razoável para o exercício da atividade normogenética. Essa infração omissiva pode ser: a) própria - decorre do dever jurídico de produção normativa. Ex: determinação constitucional; ou, b) imprópria - mesmo diante da inexistência de um prazo determinado, provém da ausência de regulamentação de determinado preceito jurídico, impossibilitando o exercício de um direito assegurado pela constituição -, e, por fim, quando a produção normogenética atinja um grupo delimitado de pessoas.

\section{0 ordenamento jurídico pátrio no que tange à concessão de benefícios fiscais e seu funda- mento}

\subsection{Os fundamentos legais à concessão de benefí- cios fiscais}

Considerando que nossa abordagem diz respeito à responsabilização do ente estatal em razão da edição de leis inconstitucionais alusivas à concessão de benefícios fiscais, indispensável que se apresentem aqui as leis e seus dispositivos pertinentes ao regramento próprio e delimitador quanto à possibilidade de concessão dos tais, para que tenham plena validade e, então, cumpram a finalidade precípua ditada pelo nosso ordo juris.

Verdade é que, ainda que com recuos no curso da história, ao longo do tempo, foi-se ampliando as competências estaduais e diminuindo o poder de regulação da União no que tange aos tributos estaduais, ainda que este com certas restrições, como, por exemplo, mantendo-se a edição de leis complementares no poder da União, com destaque para o ICMS. Poder esse, aliás, decorrente da competência constitucional ${ }^{3}$ de proporcionar a superação das desigualdades regionais. ${ }^{4}$

Pois bem, com a sanção da Lei Complementar no 24, de janeiro de 1975, nasceu no Brasil, a previsão legal dispondo "[...] sobre os convênios para a concessão de isenções do imposto sobre operações relativas à circulação de mercadorias", em que consta, expressamente, que, para a concessão de benefício fiscal por meio de convênios ${ }^{5}$ por parte de alguma Unidade Federada, indispensável sua aprovação por unanimidade dos membros do CONFAZ, ${ }^{6}$ segundo preceito do $\$ 2^{\circ}$ do art. $2^{\circ} .^{7}$ Não é demais lembrar que a referida LC no $24 / 75$ foi recepecio-

3 "Art. 21. Compete à União: [...] IX - elaborar e executar planos nacionais e regionais de ordenação do território e de desenvolvimento econômico e social.” Ainda: “Art. 174. Como agente normativo e regulador da atividade econômica, o Estado exercerá, na forma da lei, as funções de fiscalização, incentivo e planejamento, sendo este determinante para o setor público e indicativo para o setor privado. $\$ 1^{\circ}$ - A lei estabelecerá as diretrizes e bases do planejamento do desenvolvimento nacional equilibrado, o qual incorporará e compatibilizará os planos nacionais e regionais de desenvolvimento", dentre outros.

4 De fato, no que tange a segunda atuação, o poder da União de garantir recursos financeiros (crédito farto das principais agências de fomento federais) e os sistemas alocativos e decisórios concentrados nos grandes blocos do setor produtivo estatal garantiriam a acomodação dos conflitos existentes, dando à União a capacidade de planejar e de executar um projeto de desenvolvimento nacional. CALCIOLARI, Ricardo Pires. Aspectos jurídicos da guerra fiscal no Brasil. Cad. Fin. Públicas., Brasília, n. 7, p. 9, dez. 2006.

5 "Art. $1^{\circ}$ - As isenções do imposto sobre operações relativas à circulação de mercadorias serão concedidas ou revogadas nos termos de convênios celebrados e ratificados pelos Estados e pelo Distrito Federal, segundo esta Lei. Parágrafo único - O disposto neste artigo também se aplica: I - à redução da base de cálculo; II - à devolução total ou parcial, direta ou indireta, condicionada ou não, do tributo, ao contribuinte, a responsável ou a terceiros; III - à concessão de créditos presumidos; IV - à quaisquer outros incentivos ou favores fiscais ou financeiro-fiscais, concedidos com base no Imposto de Circulação de Mercadorias, dos quais resulte redução ou eliminação, direta ou indireta, do respectivo ônus; $\mathrm{V}$ - às prorrogações e às extensões das isenções vigentes nesta data."

6 Órgão de deliberação colegiada, formado por representantes de cada unidade da federação (Estados e Distrito Federal = Secretários de Fazenda) e um integrante da União (Ministro da Fazenda), cujo fim é deliberar sobre a concessão de incentivos tributários alusivos ao ICMS.

7 "Art. $2^{\circ}$ - Os convênios a que alude o art. $1^{\circ}$, serão celebrados em reuniões para as quais tenham sido convocados representantes de todos os Estados e do Distrito Federal, sob a presidência de representantes do Governo federal. [...] $₫ 2^{\circ}$ - A concessão de benefícios dependerá sempre de decisão unânime dos Estados representados; a sua revogação total ou parcial dependerá de aprovação de quatro quintos, pelo menos, dos representantes presentes." 
nada expressamente pela nova ordem constitucional, por meio do art. $34, \S 8^{\circ}$ do Ato das Disposições Constitucionais Transitórias - ADCT. ${ }^{8}$

Ademais, a própria Constituição, em seu bojo, previu no artigo alusivo ao ICMS o embasamento constitucional para a concessão de benefícios fiscais no art. 155, $\$ 2^{\circ}$, inciso XII, alínea ' $\mathrm{g}$.'

\subsection{Algumas razões que fundamentam a concessão de benefícios fiscais}

Não é de se duvidar que várias podem ser as causas que deram origem à concessão de benefícios fiscais no Brasil, gerando o que passou a se denominar de guerra fiscal. ${ }^{10}$ Lendo, contudo, a doutrina sobre o assunto, algumas delas são pinceladas e, no caso do nosso estudo, úteis à inteireza da matéria de fundo, pois, ao final, darão estribo à ilação formulada.

Além, obviamente, do interesse dos entes federados, sobretudo aqueles que ao longo da história ficaram à margem do progresso, pelo desenvolvimento de seus rincões, posto que prenunciado expressamente pela Car-

\footnotetext{
8 "Art. 34. O sistema tributário nacional entrará em vigor a partir do primeiro dia do quinto mês seguinte ao da promulgação da Constituição, mantido, até então, o da Constituição de 1967, com a redação dada pela Emenda no 1 , de 1969, e pelas posteriores. [...] $\$ 5^{\circ}$ - Vigente o novo sistema tributário nacional, fica assegurada a aplicação da legislação anterior, no que não seja incompatível com ele e com a legislação referida nos $₫ 3^{\circ}$ e $\$ 4^{\circ}$. [...] $₫ 8^{\circ}$ - Se, no prazo de sessenta dias contados da promulgação da Constituição, não for editada a lei complementar necessária à instituição do imposto de que trata o art. 155, I, "b", os Estados e o Distrito Federal, mediante convênio celebrado nos termos da Lei Complementar $\mathbf{n}^{\circ} \mathbf{2 4}$, de 7 de janeiro de 1975, fixarão normas para regular provisoriamente a matéria."

9 "Art. 155. Compete aos Estados e ao Distrito Federal instituir impostos sobre: (Redação dada pela Emenda Constitucional no 3, de 1993) [...] $₫ 2^{\circ} \mathrm{O}$ imposto previsto no inciso II atenderá ao seguinte: (Redação dada pela Emenda Constitucional no 3, de 1993) [...] XII - cabe à lei complementar: serviços e de mercadorias; [...] g) regular a forma como, mediante deliberação dos Estados e do Distrito Federal, isenções, incentivos e benefícios fiscais serão concedidos e revogados."

${ }^{10}$ Guerra fiscal - ausência de uma política fiscal em cenário de enormes desigualdades regionais em todo o país, onde cada Estado implementa políticas fiscais unilaterais criando mecanismos capazes de permitir o desenvolvimento econômico e social regional. A partir de 1980, em razão de drástica redução de investimentos públicos federais, deu-se, como conseqüência, o acirramento da guerra fiscal, através de políticas à revelia do ordenamento jurídico pátrio, resultando na crítica situação pela qual atravessava o país. Incentivos Fiscais e as ADIN’s, p. 2. Disponível em: <, http://www.abit.org.br/ ABIT_HelcioHonda.pdf>
}

ta Política de 1988, como programa a ser alcançado por meio de diversos dispositivos, ${ }^{11}$ outras razões são destacadas. Uma delas é lembrada por Fernando Facury Scaff ao destacar que, ao menos, "[...] sua intensificação aos níveis hoje encontrados de retaliação fiscal decorre da implantação da sistemática do fundo de Compensação de Exportações criado pela Lei Kandir (Lei Complementar 87/1996)". ${ }^{12}$

Helcio Honda, por sua vez, aponta, sinteticamente algumas causas que deram ensejo aos incentivos fiscais e financeiros e, por conseguinte, à entitulada guerra fiscal, sendo: a) falta de política fiscal em cenário de enormes desigualdades regionais no país; b) drástica redução de investimentos públicos federais, a partir da década de 1980; e, c) políticas públicas à revelia do ordenamento jurídico nacional. ${ }^{13}$

Ricardo Pires Calciolari, que também se dedicou a estudar a matéria, aduz que conta muito "[...] a busca por menores custos produtivos [...] e, nesse bojo, os custos tributários são sempre considerados, mormente na época atual, em que vivenciamos sobrecarga tributária crescente". ${ }^{14}$

Portanto, como podemos perceber, razões existem aos borbotões para explicar porque os entes federados optam por conceder benefícios fiscais àqueles investidores ávidos por redução de seus custos de produção, claro, contando que tais investimentos repercutirão em contrapartida ao próprio Estado por meio da geração de emprego, do crescimento econômico, da ampliação do IDH da região, enfim, progresso, e claro, com uma rebarba político eleitoral.

\subsection{Posição do supremo tribunal federal no que tange às legislações estaduais que concedem incentivos fiscais}

Há quem pense que só recentemente, em razão do julgado de 14 Ações Diretas de Incostitucionalidade,$^{15} \mathrm{em}$

${ }^{11}$ Vide nota de rodapé 1 , dentre outros.

${ }^{12}$ SCAFF, Fernando Facury. A responsabilidade tributária e a inconstitucionalidade da guerra fiscal. In: ROCHA, Valdir de Oliveira.(Cood.). Grandes questões atuais do direito tributário. São Paulo: Dialética, 2011. p. 44.

${ }^{13}$ HONDA, Helcio. Incentivos fiscais e as ADIN's. Disponível em: <http://www.abit.org.br/ABIT_.pdf >. Slide 2.

${ }^{14}$ HONDA, Helcio. Incentivos fiscais e as ADIN's. Disponível em: <http://www.abit.org.br/ABIT_.pdf>

${ }^{15}$ ADIs 1247, 2352, 2376, 2549, 2688, 2906, 3413, 3664, 3674, $3702,3794,3803,4152$ e 4457. 
conjunto, na sessão de julgamento realizada no dia $1^{\circ}$ de junho de 2011, o Supremo Tribunal Federal se posicionou sobre a incontitucionalidade dessas leis concessivas de benefícios fiscais. Engano! Há muito o STF vem sinalizando quanto à impropriedade desses benefícios à luz do ordenamento jurídico, como, por exemplo, quando julgou a ADI 84-MC/MG, Rel. Min. Sidney Sanches, de 27 de setembro de 1989. Como escreveu Fernando Facury Scaff, no que tange à validade da $\mathrm{LC}$ n $24 / 75$, “[...] o STF sempre validou essa norma coibindo de forma sistemática e sem tergiversação, todos os casos que lhe chegou às mãos". ${ }^{16}$

Das ADIs julgadas, a que mais se destacou foi a ADIn 3.246, do Estado do Pará. ${ }^{17}$ Isso porque, quando de seu julgamento, a lei acoimada de inconstitucionalidade ainda estava em vigor, ${ }^{18}$ permitindo que o STF adentrasse no mérito ${ }^{19}$ e a retirasse do plano de validade, sem, ao menos ainda, ${ }^{20}$ modular os efeitos da decisão. ${ }^{21}$

O julgamento repercutiu muito, senão pela declaração de inconstitucionalidade, mas pelo fato de o STF não ter modulado os efeitos da decisão, nem sinalizando que o faria, como ficou patente no debate entre os ministros quando do julgamento, destacando-se a fala do Min. Ricardo Lewandowski e do Min. Gilmar Mendes. Verbis:

${ }^{16}$ Op. cit., p. 47

${ }^{17}$ Rel. Min. Carlos Brito. Julgamento realizado em 19 de abril de 2006.

${ }^{18}$ O STF sempre teve por praxe julgar apenas as Ações Diretas de Inconsticionalidade cujas leis apontadas como viciadas, ainda estivessem em vigor. Nesse caso particular de concessão de benefícios fiscais, dificilmente o STF conseguia julgar o mérito, dado uma estratégia dos Estados, qual seja, assim que as Ações estavam aptas a julgamento, os governos revogavam as leis e, ato contínuo, editavam outras com igual teor. No dizer de Facury Scaff "[...] um jogo de faz de conta”. SCAFF, Fernando Facury. A responsabilidade tributária e a inconstitucionalidade da guerra fiscal. In: ROCHA, Valdir de Oliveira.(Cood.). Grandes questões atuais do direito tributário. São Paulo: Dialética, 2011. p. 48.

${ }^{19}$ O STF já sinalizou que não mais deixará de julgar a inconstitucionalidade de uma lei, nessa hipótese, quando o Estado revogar a lei às vésperas do julgamento, apenas para editar outro de igual teor, e inviabilizar a declaração de inconstitucionalidade. Vide Jornal Valor Econômico de 8 de agosto de 2011. "STF aplica Nova tese e julga Leis já Revogadas."

${ }^{20}$ Dessa decisão pende o julgamento de Embargos de Declaração, razão pela qual não se deu, ainda, o trânsito, em julgado.

${ }^{21}$ Art. 27 da Lei no 9.868/99. "Art. 27. Ao declarar a inconstitucionalidade de lei ou ato normativo, e tendo em vista razões de segurança jurídica ou de excepcional interesse social, poderá o Supremo Tribunal Federal, por maioria de dois terços de seus membros, restringir os efeitos daquela declaração ou decidir que ela só tenha eficácia a partir de seu trânsito em julgado ou de outro momento que venha a ser fixado."
O Senhor Ministro Ricardo Lewandowski - Em relação ao efeito prospectivo, trata-se de renúncia de receitas públicas de forma inconstitucional. Isso não pode se referendado por esta Corte, porque, conforme já foi dito, abriria um precendente muito perigoso.

O Senhor Ministro Gilmar Mendes - [...] todos os Estados estão absolutamente avisados de se tratar de inconstitucionalidade evidente à luz da jurisprudência tradicional do Supremo Tribunal Federal, desde 1989, conforme explicitado pelo eminente Ministro Sepúlveda Pertence.

\subsection{A consequência legal prevista pelo ordenamen- to jurídico para o ente federado que teve a lei concessiva de benefício fiscal julgada inconsti- tucional, e sua aplicação prática}

Julgada inconstitucional uma lei concessiva de benefício fiscal por desrespeitar a LC no 24/75, há sim, a nosso ver, consequências ao Estado, a despeito de se posicionar de forma diversa Ricardo Pires Calciolari. ${ }^{22}$ Tais implicações sancionatórias estão previstas na própria LC $n^{\circ} 24 / 75$, em seu artigo $8^{\circ}$ :

Art. $8^{\circ}$ - A inobservância dos dispositivos desta Lei acarretará, cumulativamente:

I - a nulidade do ato e a ineficácia do crédito fiscal atribuído ao estabelecimento recebedor da mercadoria;

II - a exigibilidade do imposto não pago ou devolvido e a ineficácia da lei ou ato que conceda remissão do débito correspondente.

No Brasil, o único caso que poderíamos ter experimentado o resultado prático dessa previsão sancionatória - o exemplo do Estado do Pará abarcado pela ADI 3.246/PA - não se manifestou em razão de ter-se encontrado uma solução brasileiríssima - o próprio CONFAZ

\footnotetext{
${ }^{22}$ Esse autor, embora reconheça existir no texto da LC n 24/75 sanções àquele que descumprir seus ditames, entende que elas são incompatíveis com a Lei de Responsabilidade Fiscal $\mathrm{n}^{\mathrm{o}} 101$, de 4 de maio de 2000, embora não esclareça no seu trabalho, em que há incompatibilidade. Op. cit. p. 22.
} 
editou Convênio liberando-o da sanção. ${ }^{23}$ Infelizmente, a resolução do problema nesses moldes, tirou do Judiciário a resposta para o caso concreto quanto à modulação ou não dos efeitos da decisão, restando, então, a dúvida: como ficariam as empresas ${ }^{24}$ diante da cobrança por parte dos Estados de todos os investimentos realizados em decorrência da confiança legítima na lei concessiva vigente por vários anos? $?^{25}$

$E$ É a isso que queremos responder, id est, tendo os Estados que concederam benefícios fiscais a empresas suas leis julgadas inconstitucionais pelo STF, sem modulação dos efeitos, ou seja, com efeitos ex nunc - desde o início de sua vigência -, e, partindo do pressuposto de não agir o CONFAZ, como fez no caso do Pará, promovendo verdadeira anistia, poderão as empresas, não só por sofrerem exigência dos valores desonerados até então, mas também, deixarem de beneficiar-se ao longo do tempo contratado, a despeito de terem cumprido sua parte obrigacional, qual seja, realizados os investimentos listados, promovido a geração de empregos prevista no projeto de viabilização do negócio, dentre outros compromissos eventualmente assumidos?

\footnotetext{
${ }^{23}$ No dizer de Facury Scaff, "[...] usou-se do veneno para encontrar a cura. O Convênio ICMS 2, de 20 de janeiro de 2010, publicado no DOU de 21 de janeiro de 2010, autorizou o Estado do Pará a 'não exigir débitos fiscais previstos nos atos a seguir relacionados, desconstituídos judicialmente por não atender o disposto no art. 155, $\$ 2^{\circ}$, XII, 'g', da Constituição Federal: art. $5^{\circ}$, inciso I, da Lei ${ }^{\circ}$ 6.489, de 27 de dezembro de 2002, do Estado do Pará.' Esta norma também foi aplicada ao Estado de Rondônia por estar em situação semelhante." SCAFF, Fernando Facury. A responsabilidade tributária e a inconstitucionalidade da guerra fiscal. In: ROCHA, Valdir de Oliveira. (Coord.). Grandes questões atuais do direito tributário. São Paulo: Dialética, 2011. p. 50.

${ }^{24}$ Fernando Facury Scaff na obra citada anteriormente trabalha essa mesma questão, porém, com foco sobre a hispótese de poder ou não os Estados que tiverem suas leis julgadas inconstitucionais exigir das empresas todo o valor desonerado.

${ }^{25}$ Nossa indagação é pertinente, a uma, porque no caso citado Pará, o STF não havia modulado os efeitos da decisão, o que implicava na não validade dos atos praticados sob a vigência daquela lei e, tendo em conta o disposto no art. $8^{\circ}$, inciso I e II da LC 24/75, deveriam as empresas benefíciárias sofrer a cobrança dos impostos não pagos; e, a duas, porque, independentemente do caso exemplificativo, houve, como dissemos, decisão recente, em que 14 legislações foram excluídas do ordenamento, por inconstitucionalidade, e podem, eventualmente, não ter modulado os seus efeitos. Portanto, cuida de outro enfoque. Da hipótese de não haver modulação dos efeitos da decisão, tendo, portanto, as empresas que sujeitar-se à exigibilidade dos valores de tributos desonerados.
}

\section{A obrigação dos Estados que tiveram leis concessivas de benefícios fiscais julgadas inconstitucionais sem efeitos prospectivos em reparar os danos causados às empresas beneficiárias pelos investimentos realizados sob essa condição}

\subsection{A prática comum decorrente dessas concessões fiscais}

A hipótese por nós ventilada a despeito de parecer inviável de ocorrer na prática, não o é. Tanto que não só já experimentamos um caso (ADIn 3.246), em que o STF julgou inconstitucional a lei estadual, frisa-se, sem efeitos prospectivos, ${ }^{26}$ embora o CONFAZ acabasse por resolver a questão por meio de Convênio, liberando os Estados cedentes dos benefícios, como também, estamos no momento atual, vivendo essa situação de expectativa ante a decisão pelo STF quanto à inconstitucionalidade de 14 leis estaduais supracitadas e, ressalte-se uma vez mais, sem aplicação de efeitos prospectivos.

$\mathrm{Na}$ prática, um Estado, desejando atrair negócios interessantes para seu território, tem a expectativa de que isso acarretará: a) a vinda de empresas de grande porte, reconhecidas no cenário nacional ou multinacional; b) a construção de indústrias, fábricas, armazéns, enfim, negócios fincados em um dado município, geralmente onde haja um Distrito Agroindustrial; c) a vinda de determinado número de empregados, geralmente de alto escalão (executivos = gestores), com suas famílias, que passarão a morar na localidade e a utilizar do comércio, do sistema educacional, das entidades de classes e da vida pública, agregando valor social à comunidade; d) a contratação de pessoas da região, gerando empregos que repercutam favoravelmente na economia local, em razão dos salários e benefícios que serão pagos aos trabalhadores; e) por mais que pareça contraditório, uma vez que estamos analisando a concessão de incentivos fiscais, ${ }^{27}$ todavia, há acréscimo no pagamento de tributos, seja de parte daquele que se concede benefício, posto que a desoneração quase nunca é total, mas também, porque implica em pagamentos de tributos municipais como, por exemplo, ISS, IPTUs, ITUs, taxas decorrentes do poder de polícia (Ex: certidão de uso do solo) ou pela prestação de serviços pú-

\footnotetext{
${ }^{26}$ É verdade que ainda pendem Embargos de Declaração a serem julgados, como citado em linhas pretéritas.

${ }^{27}$ Nossa hipótese, pela peculiaridade do tema, se restringe ao ICMS.
} 
blicos (Ex: limpeza urbana); f) desenvolvimento econômico regional, posto que, não raras vezes, instalando-se uma indústria, outras atividades comerciais ou mesmo industriais de menor porte, indispensáveis à fabricação do produto da empresa beneficiada, se estabelecerão na mesma região; entre tantos outros itens que poderíamos aqui citar pertinentes à cadeia produtiva da empresa que contrata com o Poder Público debaixo de uma lei concessiva de incentivos fiscais. ${ }^{28}$

Para tanto, editada uma lei de iniciativa do Executivo que, enviada à Assembleia Legislativa, é aprovada, possibilitando, então, ao Estado firmar contratos com empresas dos mais variados setores, ${ }^{29}$ concedendo inúmeros benefícios fiscais, ${ }^{30}$ geralmente, depois de analisados uma Carta Consulta, o projeto de implantação do negócio, com os números pojetados de geração de empregos, capacidade de desenvolvimento econômico e social à região, capacidade de produção e estimativa de tempo para sua implantação e produção na sua capacidade máxima.

Os contratos estipulam em suas cláusulas os benfícios e as condições a serem observados para fazer jus aos tais, além da estipulação de uma garantia para a hipótese de não cumprir o contrato e ter utilizado benefícios em um determinado período.

Quase nada se fala, entretanto, no sentido oposto, qual seja, se a empresa cumprir todas as suas obrigações e o Estado não honrar com aquilo que foi contratado, salvo dizeres genéricos nas cláusulas, ainda que não com esses termos, quanto à legalidade e à segurança jurídica ínsitas

\footnotetext{
${ }^{28}$ Sabemos que com a instalação de uma indústria em um determinado lugar, problemas outrora inexistentes também podem advir, como: a) estragos na infraestrutura asfáltica, em razão de eventual presença de veículos de cargas pesadas; b) poluição ao meio ambiente local; c) pagamento de salários abaixo da média nacional; d) distribuição dos resultados do negócio para outros lugares, que não a localidade ou mesmo o Estado etc. Todavia, ainda que essas questões não sejam impossíveis de se verificar, entendemos que no ato da contratação do benefício fiscal previsto em lei, as empresas assumem tantos compromissos relacionados a essas áreas passíveis de problemas, que, ou elas são evitadas, ou, se ocorrerem, haverá ao Estado meios de ajustar tais problemas extra ou judicialmente.

${ }^{29}$ Há casos em que as leis, embora sejam de conteúdo genérico, visam à inserção no mercado local de uma empresa específica, em face de contatos pré-estabelecidos.

${ }^{30}$ Isenção, diferimento, redução de base de cálculo, crédito presumido, entre outros.
}

ao negócio. Não obstante, a ausência de qualquer cláusula no sentido de responsabilizar o Estado por eventual dano à empresa, a nosso ver, é desnecessário, posto que nosso ordenamento não exige que a reparação esteja prevista em contrato. Ela decorre de previsão legal, ${ }^{31}$ a começar por impor que os pactos observem certas formalidades sob pena de invalidade. ${ }^{32}$

Pois bem, considerando que, em decorrência da decisão do STF julgando inconstitucional a lei estadual, sem efeitos prospectivos, o resultado prático sobre as empresas que investiram no Estado, cumprindo sua parte contratada, será, primeiro, perder de pronto a possibilidade de utilização dos benefícios daquele momento em diante e, ato contínuo, ser cobrado pelos valores que deixou de arrecadar aos cofres públicos em decorrência dos benefícios fiscais tributários. ${ }^{33}$

Se nenhuma outra consequência danosa decorrer daí, só isso, a nosso ver, poderá dar ensejo à reparação dos danos, emergentes e cessantes, obviamente que observados os requisitos indispensáveis à caracterização dele, como provar a existência de nexo de causalidade entre a contratação com base em lei (agente no exercício da função) julgada inconstitucional (conduta do agente em produzir lei inconstitucional) e o dano produzido (perda do benefício contratado e esperado).

É verdade que os Estados, em suas defesas, hão de dizer que não há inocentes nisso, pois as empresas também sabiam do risco de sua lei ser declarada inconstitu-

\footnotetext{
${ }^{31}$ Previsão constitucional: "Art. 5. Todos são iguais perante a lei, sem distinção de qualquer natureza, garantindo-se aos brasileiros e aos estrangeiros residentes no País a inviolabilidade do direito à vida, à liberdade, à igualdade, à segurança e à propriedade, nos termos seguintes: [...] V - é assegurado o direito de resposta, proporcional ao agravo, além da indenização por dano material, moral ou à imagem [...]" "Art. 186. Aquele que, por ação ou omissão voluntária, negligência ou imprudência, violar direito e causar dano a outrem, ainda que exclusivamente moral, comete ato ilícito." e, "Art. 927. Aquele que, por ato ilícito (arts. 186 e 187), causar dano a outrem, fica obrigado a repará-lo. Parágrafo único. Haverá obrigação de reparar o dano, independentemente de culpa, nos casos especificados em lei, ou quando a atividade normalmente desenvolvida pelo autor do dano implicar, por sua natureza, risco para os direitos de outrem." - Código Civil, Lei nº 10.406 , de 10 de janeiro de 2002.

${ }^{32}$ Arts. 166 a 184 do CC/02.

${ }^{33}$ Vejam que não estamos indo adiante, no que tange à possibilidade ou não de incidência de juros e multas. Isso extrapola nosso intento aqui, pois ainda que apenas o tributo desonerado seja exigido no seu valor principal, a nosso ver, já há dano.
} 
cional. Ainda que, assim como as empresas, os Estados obedeceram à lei enquanto vigente na ordem jurídica.

Todavia, a nosso ver, esses argumentos não são suficientes para deixar o Estado em situação favorável, qual seja, podendo declarar inválidos os atos praticado e os contratos firmados, exigindo os valores desonerados, sem que nada estivesse ao alcance das empresas beneficiárias, porém, cujos benefícios não só cessaram, mas, aqueles usufruídos, terão que ser devolvidos. $\mathrm{E}$, outro meio não haverá, senão que a ação de reparação de danos, em que a responsabilidade civil do Estado emergirá.

\subsection{A hipótese de responsabilização de Estado que glosa crédito de empresa beneficiária de incentivo fiscal-tributário de outra unidade federada}

Uma situação que se tornou relativamente comum nessa guerra fiscal foi o fato de alguns Estados, sobretudo os mais industrializados, ${ }^{34}$ sentindo-se ameaçados pela transferência de empresas de seu território para outras unidades federativas, legislarem ${ }^{35}$ glosando créditos $^{36} \mathrm{de}$ seus contribuintes em razão da aquisição de produtos de empresas detentoras de benefícios fiscais em outros Estados, sob o argumento da inconstitucionalidade de tais benefícios. Isso fez surgir dois tipos de problemas, sendo um deles em relação aos próprios contribuintes internos ao terem seus créditos glosados, e outro em relação

\footnotetext{
${ }^{34}$ O Estado de São Paulo é o protagonista nesse cenário.

${ }^{35}$ Lei n $^{\circ}$ 6374/89: “Art. $36 \$ 2^{\circ}$ - Não se considera cobrado, ainda que destacado em documento fiscal, o montante do imposto que corresponder a vantagem econômica decorrente da concessão de qualquer subsídio, redução da base de cálculo, crédito presumido ou outro incentivo ou benefício fiscal em desacordo com o disposto no artigo $155, \S 2^{\circ}$, inciso XII, alínea 'g' da Constituição Federal". (Mesma redação do artigo 59, parágrafo segundo do RICMS/00 - Decreto nº 45490/00). Vide também, Comunicado CAT no 36/2004.

${ }^{36}$ PORTARIA CAT No 56, DE 14 DE JUNHO DE 1993 (DOE DE 15.06.93): Veda a apropriação de crédito de ICMS, na proporção que especifica relativamente as entradas de mercadorias de procedência estrangeira, remetidas por empresas do Estado do Amazonas, beneficiárias de incentivos fiscais. Portaria CAT No 85, DE 03 DE SETEMBRO DE 1993 (DOE DE 04.09.93 - RETIFICADA NO DOE 10.09.93): Dispõe sobre a apropriação de crédito do ICMS, na proporção que específica, relativamente à entrada de mercadoria de procedência estrangeira, remetida por empresa do Estado do Espírito Santo, beneficiaria dos incentivos mencionados no art. 155, parágrafo $2^{\circ}$, XII, "g", da Constituição Federal. RESOLUCAO SF No 52, DE 19 DE NOVEMBRO DE 1993 (DOE DE 20.11.93): Dispõe sobre a apropriação do crédito do ICMS em operação interestadual efetuada por empresa favorecida com incentivos ou benefícios fiscais.
}

às empresas sediadas em outras Unidades da Federação detentoras de benefícios fiscais, posto que, passaram imediatamente a fazer parte de uma virtual lista negra, perdendo vendas, uma vez que seus clientes tinham receio em sofrer retaliações do fisco local.

Também essa postura adotada pelos Estados mais industrializados, retaliando a postura dos demais Estados concedentes de benefícios fiscais e das empresas neles instaladas, detentoras de tais benefícios, chegou aos tribunais $^{37}$ e foi rechaçada, inclusive, definitivamente pelo Supremo Tribunal Federal.

Dessa maneira, o STF, ao apreciar essa postura imperial, dispôs com propriedade, destacando-se a Ementa da lavra do Min. Sepúlveda Pertence:

2. As normas constitucionais, que impõe disciplina nacional ao ICMS, são preceitos contra os quais não se pode opor a autonomia do Estado, na medida em que são explícitas limitações.

3. O propósito de retaliar preceito de outro Estado, inquinado da mesma balda, não valida a retaliação: inconstitucionalidades não se compensam. ${ }^{38}$

Outros casos já foram apreciados e decididos na mesma linha, tanto no STF (AC 2.611/MG, Rel. Min. Ellen Gracie), como no Superior Tribunal de Justiça - STJ, que tem adotado o mesmo entendimento (RMS 31.714/ MT, Rel. Min. Castro Meira).

Demonstrados os fatos e a remançosa jurisprudência sobre eles, que inadmite tal retaliação, não temos como concluir de forma diversa, senão que, também nessa hipótese, o Estado que inconstitucionalmente retaliar contribuinte seu e outro Estado federativo, dá ensejo à reparação dos danos causados, porque age, tal como o outro, inconstitucionalmente e, no dizer no Min. Sepúlveda Pertence, "[...] inconstitucionalidades não se compensam" ${ }^{39}$

\section{Conclusão}

Discorrida toda essa abordagem, seja sob o aspecto da responsabilidade civil em si, seja sob as questões

\footnotetext{
${ }^{37}$ Apelação Cível no 017.385-5/3 e na Apelação Cível n 529.2185/0 do TJSP, que declarou o Comunicado CAT n ${ }^{\circ} 36 / 2004$ inconstitucional.

${ }^{38}$ ADI 2.377-MC, DJ de 7.11.2003.

${ }^{39}$ ADI 2.377-MC, DJ de 7.11.2003.
} 
tributárias advindas dos benefícios fiscais criados por leis inconstitucionais, havemos de concluir que:

a) $\mathrm{O}$ ordenamento jurídico brasileiro evoluiu ao longo do tempo, desde a Constituição Imperial até a Constituição Cidadã, de modo a pari pasu, reconhecer a responsabilização do Estado e seus agentes;

b) A possibilidade de responsabilidade decorrente de edição legislativa, quando julgada inconstitucional definitivamente pelo STF;

c) Necessidade de que haja, para responsabilização do Estado, liame obrigacional resultante de uma inconstitucionalidade e dano efetivo;

d) Os benefícios fiscais são previstos e permitidos no Brasil, todavia, nos termos ditados pela LC no 24/75, implicando em convênio autorizativo por unanimidade dos integrantes do CONFAZ;

e) Há diversas razões que fundamentam o interesse dos Estados na concessão de benefícios fiscais, desde a necessidade de desenvolvimento de uma região menos favorecida, até questões decorrentes de políticas tributárias formuladas no âmbito nacional;

f) O STF sempre reconheceu a LC $n^{\circ}$ 24/75 como válida, coibindo, de forma sistemática, as legislações concessivas de benefícios fiscais à revelia dos ditames da LC $n^{\circ} 24 / 75$;

g) A LC no 24/75 é assaz clara ao prever em seu art. $8^{\circ}$, I e II, as consequências àqueles que concederem benefícios à margem de seus ditames;

h) O aspecto prático na relação de quem concede benefício fiscal e de quem recebe é que este investe no território daquele, construindo infraestrutura, gerando empregos, envolvimento de seus executivos na comunidade local, aumento da renda dos trabalhadores da região, movimentação do comércio local e atração de outros negócios vinculados àquela atividade, havendo obviamente a possibilidade de aspectos negativos, todavia, sendo esses minimizados pelas obrigações contratadas com o Poder Público, impeditivas e/ou sancionadoras ou reparadoras desses eventuais danos;

i) Havendo a cessação do benefício em razão da inconstitucionalidade, a empresa perde o benefício da- quele momento adiante e ainda será cobrada pelo que lhe foi desonerado no tempo em razão da lei à época vigente, devendo, ainda que só por esse dano, ser indenizada pelo Estado;

j) Há Estados, regra geral os industrializados, que descontentes com a perda de empresas em seus territórios ou com a forma que elas são atraídas pelos demais Estados, editam leis, criando obstáculos não só aos seus contribuintes que adquirirem produtos dessas empresas beneficiárias, glosando seus créditos fiscais de ICMS, como, por via de consequência, prejudicam as empresas beneficiárias, porque passam a ser taxadas no mercado como ilegais, reduzindo o interesse por seus produtos, minando-lhe, inconstitucionalmente, seu direito de comércio;

k) Por consequência, também nesse aspecto, não vemos dificuldades em ser o Estado obstacularizador responder por perdas e danos, até porque, como expresso em decisão do STF a esse respeito, da lavra do Min. Sepúlveda Pertence, "[...] inconstitucionalidades não se compensam".

\section{Referências}

ÁVILA, Humberto. Segurança jurídica. São Paulo: Malheiros, 2011.

CALCIOLARI, Ricardo Pires. Aspectos jurídicos da guerra fiscal no Brasil. Cad. Fin. Públicas., Brasília, n. 7, 2006.

HONDA, Helcio. Incentivos fiscais e as ADIN's. Disponível em: <http://www.abit.org.br/ABIT_.pdf $>$.

NERY JR., Nelson; NERY, Rosa Maria Andrade. Doutrinas essenciais - responsabilidade civil. São Paulo: Revista dos Tribunais, 2010.

RODRIGUESJÚNIOR, OtávioLuis; MAMEDE, Gladston; ROCHA, Maria Vital. (Coord.). Responsabilidade civil contemporânea, em homenagem a Silvio de Salvo Venosa. São Paulo: Atlas, 2011.

SCAFF, Fernando Facury. A responsabilidade tributária e a inconstitucionalidade da guerra fiscal. In: ROCHA, Valdir de Oliveira (Coord.). Grandes questões atuais do direito tributário. São Paulo: Dialética, 2011. 